\title{
ANALISIS YURIDIS SIFAT KEILMUAN \\ ANTROPOLOGI HUKUM DAN PERKEMBANGANNYA
}

\section{Adrian Putra}

\author{
Email: Putraadrian286@gmail.com \\ No BP: 2110003600274 \\ Universitas Ekasakti Padang
}

\section{A. PENDAHULUAN}

Antropologi secara etimologis berasal dari bahasa Yunani. Kata Anthropos berarti manusia atau orang dan logos berarti ilmu pengetahuan. Jadi, antropologi adalah ilmu yang mempelajari manusia. Oleh karena itu antropologi didasarkan pada kemajuan yang telah dicapai ilmu pengetahuan sebelumnya. Pitirim Sorokim mengatakan bahwa Sosiologi adalah suatu ilmu yang mempelajari hubungan dan pengaruh timbal balik antara aneka macam gejala-gejala sosial (gejala ekonomi dengan agama, keluarga dengan moral, hukum dengan ekonomi) dengan gejala lainnya (nonsosial).

Antropologi mempelajari manusia sebagai makhluk biologis sekaligus makhluk sosial. Antropologi memiliki dua sisi holistik dimana meneliti manusia pada tiap waktu dan tiap dimensi kemanusiannya. Arus utama inilah yang secara tradisional memisahkan antropologi dari disiplin ilmu kemanusiaan lainnya yang menekankan pada perbandingan/ perbedaan budaya antar manusia. Walaupun begitu sisi ini banyak diperdebatkan dan menjadi kontroversi sehingga metode antropologi sekarang seringkali dilakukan pada pemusatan penelitan pada pendudukyang merupakan masyarakat tunggal.Oleh karena itu antropologi didasarkan pada kemajuan yang telah dicapai ilmu pengetahuna sebelumnya. Dalam ilmu antropologi hukum dipelajari juga mengenai Peran, Status atau kedudukan, Nilai, Norma dan juga Budaya atau kebudayaan. Kesemuanya ini merupakan hal-hal yang sangat erat kaitannya dengan ilmu antropologi hukum

Antropologi Hukum merupakan ilmu yg mempelajari manusia dengan kebudayaan, khususnya di bidang Hukum, atau ilmu tentang manusia dalam kaitannya dengan Kaidah-kaidah sosial yang bersifat Hukum. Kebudayaan hukum adalah kekuasaan yang digunakan oleh penguasa untuk mengatur masyarakat agar tidak melanggar kaidah-kaidah sosial yang telah ada dalam masyarakat. Antropologi Hukum tidak membatasi pandangan pada kebudayaan tertentu (studi perbandingan). Masyarakat manusia dipelajari dengan cara perbandingan. Bagaimana sederhananya tahap perkembangan masyarakat, sepatutnya dipelajari di samping masyarakat 
yang budayanya sudah maju, yang tidak dibedakan secara kualitatif. Antroplogi Hukum, mempelajari masyarakat sebagai suatu keseluruhan yang utuh, dimana bagian-bagiannya saling bertautan. Antropologi Hukum Modern tidak memusatkan perhatian hanya pada kekuatan sosial dan hal superorganis. Antropologi Hukum memandang masyarakat secara Dinamis, sehingga peranan sosial dan Hukum tidak terbatas mempertahankan status quo. Antropologi Hukum termasuk ilmu Hukum yang empiris.

Satu hal yang dapat kita ambil dari antropologi hukum, adalah diharapkan dapat memunculkan kesadaran atas kenyataan adanya keberagaman hukum karena beragamnya budaya. Beragamnya hukum tersebut jangan dimaknakan sebagai pertentangan hukum(conflict of laws), tetapi patut dianggap sebagai khazanah kekayaan hukum yang akanmampu memperkuat serta memperbaharui hukum nasional. Di sisi lain akibatnya adalahmemunculkan sikap toleransi untuk menghargai umat manusia yang beragam pola fikir,karakter, pemahaman, dan tentunya juga beragam hukum.

Berdasarkan uraian di atas, maka ilmu antropologi hukum mempelajari mengenai Peran, Status atau kedudukan, Nilai, Norma dan juga Budaya atau kebudayaan. Kesemuanya ini merupakan hal-hal yang sangat erat kaitannya dengan ilmu antropologi hukum. Sehingga dapat kita simpulkan bahwa Antropologi Hukum merupakan ilmu yang mempelajari manusia dengan kebudayaan, khususnya di bidang Hukum, atau ilmu tentang Manusia dalam kaitannya dengan Kaidah-kaidah sosial yang bersifat Hukum. Kebudayaan hukum adalah kekuasaan yang digunakan oleh penguasa untuk mengatur masyarakat agar tidak melanggar kaidah-kaidah sosial yang telah ada dalam masyarakat.

\section{B. PEMBAHASAN}

\section{Sifat Keilmuan Antropologi Hukum}

Antropologi berasal dari bahasa Yunani, Antropos yang artinya manusia dan Logos yang artinya ilmu.

Ilmu tentang hayati terdiri dari:

1. Paleo Antropologi, yaitu mempelajari tentang asal usul manusia dan perkembangannya. Metode yang digunakan dengan penggalian fosil-fosil. Bagian yang dipelajari adalah organ organ dalam tubuh. 
2. Antropologi Fisik, yaitu mempelajari bentuk-bentuk manusia, baik bagian dalam maupun bagian luar tubuh. Tujuannya mempelajari corak ragam manusia.

Antropologi mempelajari perkembangan kehidupan manusia dan budayanya, dengan cabang-cabang ilmu, diantaranya; ilmu PraSejarah untuk mempelajari kehidupan asal usul manusia, dan untuk mengetahui ragam bahasa manusia maka harus mempelajari Etnolinguistik, sedangkan ilmu yang mempelajari cara manusia berbangsa dan berbudaya disebut Etnologi. Antropologi adalah studi ilmu yang mempelajari tentang manusia dari Aspek Budaya, Perilaku, Nilai, Keanekaragaman, dan lainnya. Antropologi terbagi dalam: Antropologi Ekonomi, Antropologi Politik, Antropologi Pendidikan, dan Antropologi Hukum.

Antropologi Hukum merupakan ilmu yg mempelajari manusia dengan kebudayaan, khususnya di bidang Hukum, atau ilmu tentang Manusia dalam kaitannya dengan Kaidah kaidah sosial yang bersifat Hukum. Kebudayaan hukum adalah kekuasaan yang digunakan oleh penguasa untuk mengatur masyarakat agar tidak melanggar kaidah-kaidah sosial yang telah ada dalam masyarakat. Hukum diperlukan meski telah ada kaidah atau norma dalam masyarakat, agar terdapat keteraturan dalam kehidupan manusia melalui hukum tertulis dengan sanksi yang nyata disamping norma dan kaidah yang sanksinya lebih bersifat sosial atau akhirat. Sebagai Ilmu Pengetahuan, Antropologi Hukum dicirikan oleh 3 (tiga) hal yaitu adanya: Objek, Metode, dan Sistem Antropologi Hukum sebagai ilmu pengetahuan yang merupakan spesialisasi dari Antropologi Budaya, memiliki karakter :

1. Antropologi Hukum, adalah Ilmu pengetahuan (logos) tentang Manusia (antropos) yg berhubungan dengan Hukum

2. Manusia, adlah manusia yg hidup bermasyrakat, masyarakat yg masih sederhana budayanya (primitif) dan yg sudah Maju (modern)

3. Budaya adalah Budaya Hukum, yaitu segala bentuk perilaku budaya manusia yg mempengaruhi Masalah Hukum Budaya adalah milik bersama yang perlu dipertahankan atau dilestarikan.

Budaya hukum adalah tanggapan masyarakat terhadap suatu perbuatan yang dianggap baik, yang hal ini juga bergantung pada sikap penegak hukum. Nilai budaya atau Postulat adalah nilai yang ada dalam masyarakat modern dan masyarakat sederhana 
yang dinilai baik atau dipertahankan. Budaya adalah milik bersama yang perlu dipertahankan atau dilestarikan. Budaya hukum adalah tanggapan masyarakat terhadap suatu perbuatan yang dianggap baik, yang hal ini juga bergantung pada sikap penegak hukum.

Nilai budaya atau Postulat adalah nilai yang ada dalam masyarakat modern dan masyarakat sederhana yang dinilai baik atau dipertahankan. Masalah Hukum tidaklah hanya pada masalah hukum yang normatif (undang undang), atau masalah hukum yang merupakan pola perilaku yg sering terjadi (hukum adat), tetapi juga masalah budaya terhadap suatu masalah Hukum, adapun faktor yang mempengaruhinya:

a. Faktor-faktor Budaya yg melatarbelakangi Masalah Hukum ; misalnya, Cara-cara menyelesaikan Masalah Perselisihan dikalangan Orang Batak, tidak sama dengan orang Minang, Jawa, Bali, Maluku dan lainya

b. Cara-cara tersebut menjai Objek perhatian Antrop Hukum Kajian Antropologi Hukum adalah menggali norma dan nilai-nilai dalam masyarakat.

Arena Antropologi Hukum mempelajari manusia dan budaya hukum, karenanya kaidah sosial yang tidak bersifat hukum bukanlah sasaran pokok penelitian Antropologi Hukum. Norma / kaidah menurut Antropologi Hukum pola ulangan perilaku dalam masyarakat. Norma / Kaidah adalah nilai dasar yang ada dalam masyarakat yang dapat mengukur perilaku manusia agar dapat menilai mana perbuatan benar dan mana yang tidak benar. Norma memiliki aspek hukum ketika aparat menjatuhkan sanksi karena ada perbuatan yang menyimpang atau melanggar hukum. Sanksi bersifat positif seperti dengan membayar denda atau kerja sosial, dan sanksi bersifat negatif seperti hukuman badan atau dikucilkan.. Hukum muncul dari peradaban manusia, dimana ada 2 orang atau lebih di situ ada hukum.

Berdasarkan klasifikasi dari Sifat Keilmuan Antropologi Hukum maka dapat dibagi menjadi lima (5) kesatuan yang utuh yaitu:

1. Antropologi Hukum tidak membatasi pandangan pada kebudayaan tertentu (studi perbandingan).Masyarakat manusia dipelajari dengan cara perbandingan. Bagaimana sederhananya tahap perkembangan masyarakat, sepatutnya dipelajari di samping masyarakat yang budayanya sudah maju, yang tidak dibedakan secara kualitatif. 
2. Antroplogi Hukum, mempelajari masyarakat sebagai suatu keseluruhan yang utuh, dimana bagian-bagiannya saling bertautan.

3. Antropologi Hukum Modern tidak memusatkan perhatian hanya pada kekuatan sosial dan hal superorganis.

4. Antropologi Hukum memandang masyarakat secara Dinamis, sehingga peranan sosial dan Hukum tidak terbatas mempertahankan status quo.

5. Antropologi Hukum termasuk ilmu Hukum yang empiris.

\section{Perkembangan Antropologi Hukum}

Awal pemikiran antropologis tentang hukum dimulai dengan studi-studi yang dilakukan oleh kalangan ahli antropologi dan bukan dari kalangan sarjana hukum. Awal kelahiran antropologi hukum biasanya dikaitkan dengan karya klasik Sir Henry Maine yang bertajuk The Ancient Law yang diterbitkan pertama kali pada tahun 1861. Ia dipandang sebagai peletak dasar studi antropologis tentang hukum melalui introduksi teori evolusionistik (the evolusionistic theory) mengenai masyarakat dan hukum, yang secara ringkas menyatakan: hukum berkembang seiring dan sejalan dengan perkembangan masyarakat, dari masyarakat yang sederhana (primitive), tradisional, dan kesukuan (tribal) ke masyarakat yang kompleks dan modern, dan hukum yang inherent dengan masyarakat semula menekankan pada status kemudian wujudnya berkembang ke bentuk kontrak.

Tema kajian pada fase awal studi-studi teoritis mengenai hukum dengan pendekatan antropologis lebih difokuskan pada fenomena hukum dalam masyarakat bersahaja (primitive), tradisional (traditional), dan kesukuan (tribal) dalam skala evolusi bentuk-bentuk organisasi sosial dan hukum yang mengiringi perkembangan masyarakat manusia. Sedangkan, metode kajian yang digunakan untuk memahami fenomena hukum dalam masyarakat adalah apa yang dikenal sebagai armchair methodology, yaitu metodologi untuk memahami hukum dalam perkembangan masyarakat melalui kajiankajian yang dilakukan di belakang meja, sambil duduk di kursi empuk, dalam ruangan yang nyaman, dengan membaca dan menganalisis sebanyak mungkin documentary data yang bersumber dari catatan-catatan perjalanan para petualang atau pelancong, dari laporan-laporan berkala dan dokumen resmi para missionaris, pegawai sipil maupun para serdadu pemerintah kolonial dari daerah-daerah jajahannya. 
Pada awal abad ke-20 metode kajian hukum dari belakang meja mulai ditinggalkan, dan mulai memasuki perkembangan metode studi lapangan (fieldwork methodology) dalam studi- studi antropologis tentang hukum. Karya Barton, misalnya, yang berjudul Ifugao Law yang dipublikasikan pertama kali pada tahun 1919 merupakan hasil dari fieldwork yang intensif dalam masyarakat suku Ifugao di Pulau Luzon Philipina. Kemudian, muncul karya Malinowski berjudul Crime and Custom in Savage Society yang pertama kali dipublikasikan pada tahun 1926 adalah hasil studi lapangan yang komprehensif dalam masyarakat suku Trobrian di kawasan Lautan Pasific, dan seterusnya sampai sekarang metode fieldwork menjadi metode khas dalam studi-studi antropologi hukum.

Tema-tema kajian yang dominan pada fase awal perkembangan antropologi hukum berkisar pada pertanyaan-pertanyaan : apakah hukum itu ? apakah ada hukum dalam masyarakat yang bersahaja, tradisional, dan kesukuan ?; bagaimanakah hukum berujud dan beroperasi dalam kehidupan masyarakat ? Pada dekade tahun 1940-an sampai 1950-an tema-tema kajian antropologi hukum mulai bergeser ke mekanismemekanisme penyelesaian sengketa dalam masyarakat sederhana. Karya klasik dari Llewellyn dan Hoebel bertajuk The Cheyenne Way (1941) merupakan hasil studi lapangan kolaborasi dari seorang sarjana hukum dengan ahli antropologi dalam masyarakat suku Cheyenne (suku Indian) di Amerika Serikat.

Kemudian, Hoebel mempublikasikan The Law of Primitive Man (1954), disusul dengan karya Gluckman mengenai hukum orang Barotse dan Lozi di Afrika, karya Bohannan mengenai hukum orang Tiv, karya Gulliver mengenai hukum orang Arusha dan Ndendeuli. Karya Fallers mengenai hukum dalam masyarakat suku Soga, dan karya Pospisil tentang hukum orang Kapauku di Papua. Fase perkembangan tema studi antropologi hukum ke arah mekanisme- mekanisme peneyelesaian sengketa seperti disebutkan di atas disebut oleh F. von Benda- Beckmann (1989) sebagai fase the anthropology of dispute settlements. Pada dekade tahun 1960-an tema studi-studi antropologi lebih memberi perhatian pada fenomena kemajemukan hukum atau pluralisme hukum.

Tema pluralisme hukum pertama-tama difokuskan pada kemajemukan cara-cara penyelesaian melalui mekanisme tradisional, tetapi kemudian diarahkan kepada 
mekanisme dan institusi penyelesaian sengketa menurut hukum pemerintah kolonial dan pemerintah negara- negara yang sudah merdeka. Karya Bohannan, Gluckman, dan Gulliver misalnya, tidak secara sistematis memberi perhatian pada eksistensi mekanisme dan institusi penyelesaian sengketa menurut hukum kolonial dan hukum negara-negara sedang berkembang.

Sejak tahun 1970-an tema studi-studi antropologi hukum secara sistematis difokuskan pada hubungan antar institusi-institusi penyelesaian sengketa secara tradisional, neo-tradisional, dan menurut institusi hukum negara. Karya Nader dan Todd (1978) misalnya, memfokuskan kajiannya pada proses, mekanisme, dan institusi-institusi penyelesaian sengketa di komunitas masyarakat tradisional dan modern di beberapa negara di dunia, melalui Berkeley Village Law Projects, menjadi karya yang memperlihatkan kecenderungan baru dari topik-topik studi antropologi hukum. Publikasi lain yang perlu dicatat adalah mekanisme penyelesaian sengketa di kalangan orang Togo di Afrika karya van Rouveroy van Nieuwaal, kemudian karya F. von Benda-Beckmann (1979) dan K. von Benda-Beckmann (1984) yang memberi pemahaman tentang penyelesaian sengketa harta warisan di kalangan orang Minangkabau menurut pengadilan adat dan di pengadilan negeri di Sumatera Barat.

Fase selanjutnya studi pluralisme mekanisme penyelesaian sengketa mulai ditinggalkan, dan mulai diarahkan kepada studi-studi pluralisme hukum di luar penyelesaian sengketa. Karya Sally F. Moore (1978) misalnya, mengenai kemajemukan hukum agraris dalam kehidupan suku Kilimanjaro di Afrika, dan mekanisme dalam proses produksi pabrik garment terkenal di Amerika dapat dicatat sebagai perkembangan baru studi pluralisme hukum. Kemudian, studi- studi pluralisme hukum mulai difokuskan pada mekanisme jaminan sosial (social security), pasar dan perdagangan, mekanisme irigasi pertanian, institusi koperasi dan perkreditan di daerah pedesaan di negara-negara sedang berkembang. Studi-studi ini dikembangkan oleh Agrarian Law Department Wageningen Agriculture University.

Fase perkembangan tema pluralisme hukum yang menyoroti topik-topik penyelesaian sengketa maupun non penyelesaian sengketa, interaksi antara hukum negara, hukum rakyat, atau dengan hukum agama disebut oleh F. von Benda-Beckmann (1989) sebagai fase the anthropology of legal pluralism. Kecenderungan yang 
berkembang sejak tahun 1970-an adalah penggunaan pendekatan sejarah dalam studistudi antropologi hukum. Studi yang dilakukan Moore (1986), Snyder (1981), F. von Benda-Beckmann (1979), K. von Benda-Beckmann (1984) misalnya, secara eksplisit menggunakan kombinasi dimensi sejarah untuk menjelaskan interaksi institusi hukum negara (state law) dengan hukum rakyat (folk law) dalam kajian pluralisme hukum penyelesaian sengketa.

\section{PENUTUP}

Kajian Antropologi Hukum adalah menggali norma dan nilai-nilai dalam masyarakat. Arena Antropologi Hukum mempelajari manusia dan budaya hukum, karenanya kaidah sosial yang tidak bersifat hukum bukanlah sasaran pokok penelitian Antropologi Hukum. Norma / kaidah menurut Antropologi Hukum pola ulangan perilaku dalam masyarakat. Berdasarkan klasifikasi dari Sifat Keilmuan Antropologi Hukum maka dapat dibagi menjadi lima (5) kesatuan yang utuh yaitu:

1). Antropologi Hukum tidak membatasi pandangan pada kebudayaan tertentu (studi perbandingan).Masyarakat manusia dipelajari dengan cara perbandingan. Bagaimana sederhananya tahap perkembangan masyarakat, sepatutnya dipelajari di samping masyarakat yang budayanya sudah maju, yang tidak dibedakan secara kualitatif.

2). Antroplogi Hukum, mempelajari masyarakat sebagai suatu keseluruhan yang utuh, dimana bagian-bagiannya saling bertautan.

3). Antropologi Hukum Modern tidak memusatkan perhatian hanya pada kekuatan sosial dan hal superorganis.

4). Antropologi Hukum memandang masyarakat secara Dinamis, sehingga peranan sosial dan Hukum tidak terbatas mempertahankan status quo.

5). Antropologi Hukum termasuk ilmu Hukum yang empiris.

Sejarah perkembangan ilmu antropologi hukum tersebut, dapat disimpulkan bahwa ilmu antropologi hukum pada dasarnya adalah sub disiplin ilmu hukum empiris yang memusatkan perhatiannya pada studi-studi hukum dengan menggunakan pendekatan antropologis. Pada fase awal perkembangan antropologi hukum pendapat yang sangat dominan disini adalah 
yang menyatakan bahwa hukum itu berkembang sejalan dengan perkembangan hidup masyarakat.

Fase awal perkembangan antropologi hukum berkisar pada pertanyaan-pertanyaan: apakah hukum itu? apakah ada hukum dalam masyarakat yang bersahaja, tradisional, dan kesukuan? bagaimanakah hukum berujud dan beroperasi dalam kehidupan masyarakat? Kemudian pada abad ke-20, kajian ilmu antropologi hukum masih sebatas pada hal yang sederhana seperti pengenalan hukum.

Fase selanjutnya perkembangan antropologi hukum telah mengkaji mengenai kemajemukan atau pluralisme hukum dalam masyarakat. Dan pada fase terakhir kajian ilmu antropologi hukum telah mencapai suatu peningkatan yaitu mulai mengkaji mengenai penyelesaian sengketa yang terjadi di dalam masyarakat yang tentunya berdasarkan pada metode antropologi hukum baik secara tradisional, neo-tradisional, maupun dengan menggunakan hukum negara.

\section{DAFTAR PUSTAKA}

Darmini Roza dan Laurensius Arliman S, Peran Pemerintah Daerah Di Dalam Melindungi Hak Anak Di Indonesia, Masalah-Masalah Hukum, Volume 47, Nomor 1, 2018. https://doi.org/10.14710/mmh.47.1.2018.10-21

Laurensius Arliman S, Peranan Metodologi Penelitian Hukum di Dalam Perkembangan Ilmu Hukum di Indonesia, Soumatera Law Review, Volume 1, Nomor 1, 201. http://doi.org/10.22216/soumlaw.v1i1.3346. 
Laurensius Arliman S, Peran Badan Permusyawaratan Desa di Dalam Pembangunan Desa dan Pengawasan Keuangan Desa, Padjadjaran Journal of Law, Volume 4, Nomor 3, 2017. https://doi.org/10.15408/jch.v4i2.3433.

Laurensius Arliman S, Penanaman Modal Asing Di Sumatera Barat Berdasarkan UndangUndang Nomor 25 Tahun 2007 Tentang Penanaman Modal, Supremasi Hukum, Volume 1, Nomor 1, 2018. http://dx.doi.org/10.36441/hukum.v1i01.102 .

Laurensius Arliman S, Memperkuat Kearifan Lokal Untuk Menangkal Intoleransi Umat Beragama Di Indonesia, Ensiklopedia of Journal, Volume 1, Nomor 1, 2018, https://doi.org/10.33559/eoj.v1i1.18.

Laurensius Arliman S, Perkawinan Antar Negara Di Indonesia Berdasarkan Hukum Perdata Internasional, Kertha Patrika, Volume 39, Nomor 3, 2017, https://doi.org/10.24843/KP.2017.v39.i03.p03.

Laurensius Arliman S, Partisipasi Masyarakat Di Dalam Pengelolaan Uang Desa PascaUndangUndang Nomor 6 Tahun 2014 Tentang Desa, Jurnal Arena Hukum, Volume 12, Nomor 2, 2019, https://doi.org/10.21776/ub.arenahukum.2019.01202.5.

Laurensius Arliman S, Mewujudkan Penegakan Hukum Yang Baik Di Negara Hukum Indonesia, Dialogica Jurnalica, Volume 11, Nomor 1, 2019, https://doi.org/10.28932/di.v11i1.1831.

Laurensius Arliman S, Mediasi Melalui Pendekatan Mufakat Sebagai Lembaga Alternatif Penyelesaian Sengketa Untuk Mendukung Pembangunan Ekonomi Nasional, UIR Law Review, Volume 2, Nomor 2, 2018, https://doi.org/10.25299/uirlrev.2018.vol2(02).1587

Laurensius Arliman S, Peranan Filsafat Hukum Dalam Perlindungan Hak Anak Yang Berkelanjutan Sebagai Bagian Dari Hak Asasi Manusia, Doctrinal, Volume 1, Nomor 2,2016.

Laurensius Arliman S, Ni Putu Eka Dewi, Protection of Children and Women's Rights in Indonesiathrough International Regulation Ratification, Journal of Innovation, Creativity and Change Volume 15, Nomor 6, 2021.

Laurensius Arliman S, Gagalnya Perlindungan Anak Sebagai Salah Satu Bagian Dari Hak Asasi Manusia Oleh Orang Tua Ditinjau Dari Mazhab Utilitarianisme, Jurnal Yuridis, Volume 3, Nomor 2, 2016, http://dx.doi.org/10.35586/.v3i2.180. 
Laurensius Arliman S, Tantangan Pendidikan Kewarganegaraan Pada Revolusi 4.0, Jurnal Ensiklopedia Sosial Review, Volume 2, Nomor 3, 2020.. 